\title{
UPAYA PENINGKATAN MUTU SMP TERPADU LAMPANG KABUPATEN SUBANG PROVINSI JAWA BARAT DALAM MENCAPAI STANDAR NASIONAL PENDIDIKAN
}

\author{
Asep Priatna \\ STKIP SUBANG \\ asep_priatna@yahoo.co.id
}

\begin{abstract}
This study aims to reveal the efforts and results achieved by Lampang Subang Integrated Private Junior High School in improving the quality of learning to meet national education standards (SNP), so that it becomes a private school with a national standard school (SSN) status. This research is a survey research with a qualitative approach. The study was conducted at Lampang Subang Integrated Secondary School in West Java. As a data source are principals, deputy principals, teachers, school committees and students. Research instruments are based on eight SNP components that refer to the National Education Standards Research instrument development is adapted to the concept of National Education Standards (SNP), to build constructs of variables to be measured which are generally described in components, aspects, and indicators of each SNP, as well as for the development of school performance instruments. Thus, in the context of school performance, the benchmarks of achievement are national education standards (SNP). The data analysis used in this study is descriptive analysis. The results showed that the level of achievement of the programs that had been compiled in the RPS of Lampang Integrated Middle School had reached $90 \%$ with the main target being the achievement of the UAN level and graduation that had been implemented by the teacher both in the preparation of RPP and teaching materials had reached 85\%, Management developed by Integrated Middle School Lampang contributed significant value, especially in program planning and implementation, while the supervision and leadership of the Principal was going well, so the value obtained was quite significant, while the other components that were quite prominent were PBM and standard content which received quite good value, so can be developed further.
\end{abstract}

Keywords: Implementation of Quality Management, SSN, SNP

\section{ABSTRAK}

Penelitian ini bertujuan untuk mengungkap upaya dan hasil yang telah dicapai oleh SMP Swasta Terpadu Lampang Subang dalam meningkatkan mutu pembelajaran untuk memenuhi standar nasional pendidikan (SNP), sehingga menjadi sekolah swasta yang berstatus sekolah standar nasional (SSN). Penelitian ini merupakan penelitian survei dengan pendekatan 
kualitatif.Penelitian dilakukan di SMP Terpadu Lampang Subang Jawa Barat.Sebagai sumber data adalah kepala sekolah, wakil kepala sekolah, guru, komite sekolah dan siswa.Instrumen penelitian disusun berdasarkan delapan komponen SNP yang mengacu pada Standar Nasional Pendidikan.Pengembangan instrument penelitian disesuaikan dengan konsep Standar Nasional Pendidikan (SNP), untuk membangun konstruk variabel yang akan diukur yang pada umumnya dijabarkan dalam komponen, aspek, dan indikator dari setiap SNP, demikian juga untuk pengembangan instrumen kinerja sekolah. Sehingga, dalam konteks kinerja sekolah yang tolok ukur pencapaiannya adalah standar nasional pendidikan (SNP).Analisis data yang digunakan dalam penelitian ini adalah analisis deskriptif. Hasil penelitian menunjukkan bahwa tingkat ketercapaian program yang telah disusun dalam RPS SMP Terpadu Lampang telah mencapai 90\% dengan target utama adalah pencaian tingkat UAN dan kelulusan yang telah dilaksanakan oleh guru baik dalam penyusunan RPP dan bahan ajar telah mencapai $85 \%$, Manajemen yang dikembangkan SMP Terpadu Lampang menyumbangkan nilai yang cukup siginifikan terutama dalam perencanaan dan implementasi program, sementara pengawasan dan kepemimpinan Kepala Sekolah telah berjalan dengan baik, sehingga nilai yang didapat cukup signifikan, sementara komponen lainnya yang cukup menonjol adalah PBM dan standar isi yang mendapatkan nilai yang cukup baik, sehingga dapat dikembangkan lebih lanjut.

Kata Kunci : Implementasi Manajemen Mutu, SSN, SNP

\section{A. Pendahuluan}

Pendidikan

mempunyai

peranan yang sangat besar dalam membangun bangsa, karena melalui pendidikan akan dapat dihasilkan sumberdaya manusia yang unggul. Sumber daya yang unggul ini diharapkan akan dapat membangun bangsa dan negara. Oleh sebab itu, di era global seperti saat ini, manakala suatu pemerintahan tidak mempedulikan pembangunan sektor pendidikan secara serius dan berkelanjutan, mudah diprediksi bahwa pemerintahan negara itu dalam jangka panjang justru akan menjebak mayoritas rakyatnya memasuki dunia keterbelakangan dalam berbagai aspek kehidupan (Suyanto, 2008:3). Jika negara mengabaikan terhadap pendidikan, maka bangsa ini tidak akan pernah maju. Investasi di bidang pendidikan investasi yang akan membuahkan hasil sangat positif bagi kemajuan bangsa(Elchanan Cohn : 1979; Ace Suryadi, 2009).

Secara keseluruhan, berdasarkan data Ditjen 
Mandikdasmen Kemendikbud (2013) mutu pendidikan di Indonesia ditinjau berdasarkan nilai hasil akreditasi dari total sekolah 35.601 SMP, maka terdapat 5.243 SMP $(14,73 \%)$ dengan nilai $A, \quad 16.247$ SMP $(45,64 \%)$ dengan nilai $B$, $11.090 \operatorname{SMP}(31,15 \%)$ dengan nilai C, dan 3.021 SMP $(8,49 \%)$ tidak diketahui/tidak terakreditasi. Dari semuanya tersebut yang telah memenuhi sebagai SSN sebanyak 3.699 SMP, sementara itu target pemerintah berdasarkan Renstra adalah $75 \%$ lebih memenuhi 8 SNP atau bahkan menjadi SSN pada tahun 2015.Kedelapan SNP tersebut adalah standar kompetensi lulusan, standar isi, standar proses, standar sarana dan prasarana, standar tenaga pendidik dan kependidikan, standar manajemen, standar pembiayaan, dan standar penilaian.

Direktorat PSMP dalam beberapa tahun terakhir telah melaksanakan pembinaan kepada sekolah dengan kategori SPM dan SMP Potensial agar memenuhi SNP. Demikian juga sebelum tahun 2011 selama hampir 10 tahun telah melaksanakan pembinaan sekolah menjadi Sekolah Standar Nasional
(SSN), yaitu sekolah yang telah memenuhi SNP.

Pemenuhan standar nasional pendidikan (SNP) merupakan bagian dari upaya pemerintah dalam meningkatkan mutu pendidikan di seluruh Indonesia.Peningkatan mutu pendidikan sebagai bagian integral dari upaya pembangunan masyarakat, untuk meningkatkan kualitas sumber daya manusia (SDM) yang mampu menjawab tantangan persaingan di bidang ekonomi, social, budaya dan teknologi yang semakin kompetitif baik dalam skala regional, maupun internasional. Oleh karenanya upaya peningkatan mutu pendidikan merupakan isu strategis, karena bagaimanapun telah teridentifikasi bahwa salah satu kelemahan dalam RPJPD adalah bahwa ditengah ancaman tingginya tingkat kompetisi akibat era globalisasi.

Permasalahan pendidikan yang masih terjadi sampai saat ini dan ke depan di Indonesia umumnya adalah masalah pemerataan, mutu, relevansi, efisiensi, kualitas, manajemen dan pembiayaan pendidikan. Permasalahan tersebut hampir 
terjadi pada setiap jalur, jenjang dan jenis pendidikan.Banyak faktor yang mengakibatkan permasalahan pendidikan tersebut belum dapat diatasi. Faktor-faktor tersebut antara lain adalah kualitas dan kuantitas peserta didik itu sendiri tenaga kependidikan, kurikulum, sarana dan prasarana pendidikan, peran serta masyarakat, manajemen dan pembiayaan.

Secara kuantitatif, perkembangan penyelenggaraan pendidikan telah menunjukkan hasil yang cukup menggembirakan. Menurut data dari Dinas Pendidikan khususnya di Kabupaten Subang Jawa Barat pada tahun 2014 terdapat peningkatan jumlah sekolah pada tiap jenjangnya, dimana TK/RA meningkat 85,06\% (131 sekolah), SD/MI meningkat $10,69 \%$ (95 sekolah) SMP/SMPT/MTS meningkat 40,90\% (54 sekolah), SMA/MA meningkat 40,90\% (18 sekolah) dan SMK meningkat 7,5\% (3 sekolah) (Disdik Kab Subang ; 2014). Disamping peningkatan jumlah sekolah tentunya diikuti pula oleh peningkatan jumlah siswa pada masing-masing jenjang pendidikan.
Namun masalah lainnya yang juga dihadapi adalah besarnya indeks pendidikan yang terdiri dari dua komponen yaitu rata-rata lama sekolah dan angka melek huruf untuk penduduk yang berusia 15 tahun ke-atas, besarnya angka RLS hanya mencapai 6, 72 Angka tersebut menggambarkan seberapa lama seorang siswa mengenyam pendidikan. Semakin lama seseorang mengenyam pendidikan, semakin tinggi pula kualitas pendidikannya.Mencermati

beberapa angka pada data tersebut dapat di pahami bahwa penyelenggaraan pendidikan di tingkat SMP tidak menunjukkan perkembangan yang signifikan, indikasi ini dapat diasumsikan bahwa pendidikan menengah di Kabupaten Subang belum sepenuhnya dapat dijangkau oleh masyarakat. Berbagai alas an yang melatar belakangi diantaranya adalah pendidikan yang relative mahal, khususnya bagi masyarakat golongan menengah ke bawah, belum sepenuhnya masyarakat menyadari pentingnya pendidikan menengah ini sebagai sarana pengembangan sikap dan mental 
anak sebelum melanjutkan pendidikan ketingkat yang lebih tinggi atau bekerja.

Kebijakan strategis pemerintah Kabupaten Subang dalam bidang pendidikan untuk menghadapi ancaman tersebut adalah melakukan optimalisasi peningkatan mutu, relevansi dan daya saing di semua jenjang pendidikan.Peningkatan mutu dan relevansi diukur dari pencapaian kecakapan akademik dan nonakademik yang lebih tinggi, yang memungkinkan lulusan dapat proaktif terhadap perubahan masyarakat.Peningkatan akses pendidikan harus diimbangi dengan peningkatan mutu pendidikan, oleh karena itu perlu diupayakan peningkatan jumlah sekolah yang dapat memenuhi standar nasional pendidikan (SNP) dan indicator capaian sasaran bertambahnya jumlah sekolah standar nasional (SSN) pada semua jenjang pendidikan.

Upaya peningkatan capaian ini berkaitan erat dengan peningkatan aspek pembangunan pendidikan lain diantaranya adalah kinerja sekolah, indicator terakreditasi "A", rata-rata pencapaian nilai UAN tiga tahun terakhir mencapai 7,00 , persentase kelulusan mencapai di atas $90 \%$, animo tiga tahun terakhir lebih besar dari daya tampung, prestasi akademik dan non-akademik yang diraih, melaksanakan manajemen berbasis sekolah, relevansi kemampuan dan kualifikasi lulusan guru, rasio ideal guru dan siswa.

Renstra Dinas Pendidikan Kabupaten Subang menetapkan visi "Kabupaten Subang Tuntas Rintisan Wajib Belajar 12 tahun dan Unggul dalam Mutu Pendidikan" yang memiliki tiga sasaran utama yang tidak dapat dipisahkan yaitu pendidikan harus membuka kesempatan seluas-luasnya kepada semua lapisan masyarakat untuk memperoleh pelayanan pendidikan. Orientasi kedua berdimensi normative bagaimana seharusnya penyelenggaraan pendidikan dilaksanakan dengan mengacu pada Standar Nasional Pendidikan (SNP), dimensi ini mengisyaratkan bahwa peningkatan partisispasi masyarakat dalam pendidikan harus diimbangi dengan peningkatan mutu penyelenggaraan pendidikan, dengan demikian diharapkan 
substansi tujuan pendidikan dapat diwujudkan untuk semua jenis, jalur dan jenjang pendidikan.

Sementara dimensi ketiga adalah dimensi aplikatif dimana pendidikan harus mempunyai fungsi individual dan fungsi social, sesuai dengan tujuan pendidikan yang tertuang dalam UU No. 20 tahun 2003 tentang Sistem Pendidikan Nasional khususnya yang tertuang dalam Bab II yang menyatakan bahwa pendidikan nasional bertujuan untuk mengembangkan potensi peserta didik agar menjadi manusia yang beriman dan bertaqwa kepada kepada Tuhan Yang Maha Esa, berahlak mulia, sehat, berilmu, cakap, kreatif, mandiri dan menjadi warga Negara yang mulia, sehat, berilmu, cakap, kreatif, mandiri dan demokratis serta bertanggung jawab.

Kecamatan Subang Kabupaten Subang adalah salah satu dari 30 kecamatan di wilayah Kabupaten Subang dengan jumlah penduduk 49,960 jiwa yang terdiri dari 24,758 laki-laki, 25,202 perempuan. Kecamatan Subang mempunyai potensi dan produk unggulan di bidang pertanian, dan perkebunan.
Potensi sarana pendidikan yang terdapat pada kecamatan ini diantaranya adalah16 SMP yang terdiri dari 6 SMP Negeri dan 10 SMP swasta dengan daya tampung 1702 siswa, sementara SMP Negeri yang tersedia adalah 6 SMP Negeri. Sebagai besar SMP di wilayah kecamatan subang juga menerima siswa dari wilayah sekitar di luar kecamatan Subang, karena banyaknya diluar wilayah ini memiliki sekolah dasar yang cukup besar sejumlah 24 SD dengan siswa sebanyak 1.412 siswa. Salah satu SMP yang memiliki potensi sangat baik dalam proses pembelajaran dan prestasi adalah SMP Terpadu Lampang yang merupakan salah satu SMP Swasta di Kecamatan Subang Kabupaten Subang, yang diharapkan mampu memberikan pelayanan pendidikan berkualitas bagi masyarakat Kecamatan Subang khususnya dan masyarakat Kabuaten Subang pada umumnya.

Sekolah merupakan bagian yang lebih kecil dari pendidikan total anak dibandingkan yang sudah diasumsikan oleh kebanyakan guru dan orang tua. Selama ini, sekolah sudah dipercaya untuk menjalankan 


\section{Didaktik : Jurnal Pendidikan Guru Sekolah Dasar, ISSN : 24775673 \\ Sekolah Tinggi Keguruan dan IImu Pendidikan Subang Volume IV Nomor 1, Juli 2018}

tugas mendidik, dan dari generasi ke generasi dianggap sudah memenuhi tugasnya secara etis dan jujur. Pendidikan di sekolah sudah menjadi semacam fitur integral dari lansekap sosial ekonomi, sehingga hampir mustahil untuk menyusun pendekatan lain untuk mendidik anak-anak, paling tidak selama mereka masih dalam usia praremaja.Lembaga pendidikan khususnya sekolah baik tingkat dasar dan menengah maupun pendidikan tinggi diharapkan mampu menghasilkan generasi yang lebih siap terhadap perubahan.

Abad 21 ditandai dengan era keterbukaan, era dunia tanpa batas yang disebut dengan globalisasi. Menurut Tilaar (1998: 63), kehidupan abad 21 menuntut manusia unggul dan hasil karya yang unggul. Hal ini disebabkan masyarakat abad 21 adalah masyarakat yang terbuka yang memberikan berbagai jenis kemungkinan pilihan. Dengan sendirinya hanya manusia unggul yang dapat survive di dalam kehidupan yang penuh persaingan dan menuntut kualitas kehidupan, baik di dalam produk maupun dalam servis di dalam kehidupan bersama.

Semakin ketatnya persaingan mengharuskan perusahaan untuk memiliki kekuatan utama dalam persaingan.Kekuatan persaingan tersebut adalah kekuatan yang tak dimiliki oleh perusahaan orang. Ketika membahas situasi keunggulan kompetitif yang dimiliki satu organisasi atas organisasi lain pada bidang industri yang sama, maka para ahli manajemen cenderung memfokuskan pada beberapa karakteristik seperti spesialisasi, identifikasi merk, pemilihan saluran, kepemimpinan teknologi, integrasi vertikal, posisi biaya, pelayanan, dan kebijakan harga.

Kualitas berperan sebagai sumber daya utama keunggulan dalam persaingan (Eduardo Morato;1995). Perhatian terhadap kualitas sendiri dapat digunakan sebagai sumber daya keunggulan dalam persaingan.Bagaimanapun, kualitas adalah sesuatu yang relatif, organisasi harus terus meningkatkan kualitas produknya baik barang ataupun jasa.Manajer tingkat menengah menghadapi 


\section{Didaktik : Jurnal Pendidikan Guru Sekolah Dasar, ISSN : 24775673 \\ Sekolah Tinggi Keguruan dan IImu Pendidikan Subang Volume IV Nomor 1, Juli 2018}

permasalahan yang unik berkaitan dengan kualitas.Meski mereka memperoleh dukungan dari eksekutifnya, mereka tetap saja harus melakukan perbaikan dan perubahan (Sara Lawrence Lightfoot, 1993:311).Jika manajer tidak mendapat dukungan dari atasannya, maka mereka harus mengembangkan sendiri rencana peningkatan kualitas, menentukan alat dan teknik yang diperlukan.Bagaimanapun, untuk tetap menjadi manajer yang bijak dan efektif, maka mereka harus mengenali peluang dan keterbatasan dari ruang pengaruh mereka.Ruang-ruang pengaruh dapat menjadi sumber daya dalam peningkatan kualitas.

Pendidikan dapat dipandang sebagai industri jasa.Menurut Hanafiah et.al (1994: 5), jasa pendidikan adalah pelayanan yang diberikan kepada para pelanggan untuk memenuhi kebutuhan mereka (lihat juga Tampubolon, 2001: 6973).Maka dari itu mutu jasa pendidikan itu haruslah sesuai dengan atau melebihi kebutuhan itu. Namun perlu dipahami bahwa untuk memenuhi kepuasan pelanggan pendidikan tidaklah mudah karena beberapa faktor seperti: (a) peserta didik mempunyai kebutuhan yang berbeda-beda, (b) kebutuhan peserta didik tersebut juga dapat berubah-ubah seiring dengan perjalanan kedewasaan, pengalaman dan keyakinan persepsi mereka, (c) kemampuan, pengalaman, dan sikap para pendidik juga berbeda-beda, atau (d) lingkungan keluarga dan motivasi belajar mereka juga tidak sama. Untuk mengatasi berbagai permasalahan kualitas tersebut maka diperlukan manajemen pendidikan yang peduli terhadap kualitas layanan jasa kependidikan.

Kualitas berada pada puncak sebagian besar agenda, dan peningkatan kualitas dapat menjadi tugas terpenting yang dihadapi oleh setiap institusi. Namun, meskipun hal itu penting, banyak orang menemukan kualitas sebagai suatu konsep yang membingungkan; sulit didefinisikan, bahkan untuk diukur. Kita semua mengetahui kualitas ketika mengalaminya, tetapi menggambarkan dan menjelaskan merupakan tugas yang lebih sulit. Satu hal yang dapat kita pastikan, 


\section{Didaktik : Jurnal Pendidikan Guru Sekolah Dasar, ISSN : 24775673 \\ Sekolah Tinggi Keguruan dan IImu Pendidikan Subang Volume IV Nomor 1, Juli 2018}

yakni kualitas adalah apa yang membuat perbedaan antara berbagai hal yang unggul dari yang biasa (rata-rata). Dalam pendidikan, kualitas membuat perbedaan antara yang berhasil dan gagal.

Sebagaimana terjadi dalam dunia industri, kepuasan pelanggan menjadi titik berangkat dari kualitas.Organisasi yang memperhatikan kualitas secara serius mengetahui bahwa banyak rahasia kualitas berasal dari mendengarkan dan menanggapi secara simpatik berbagai kebutuhan dan keinginan pelanggan atau klien. Kualitas pada dasarnya melibatkan pelaksanaan berbagai macam hal secara baik, tetapi sebelum sebuah lembaga mengutamakan pelanggan, maka prekondisi untuk mengembangkan kualitas tidak akan ada.

Kualitas layanan atau jasa lebih sulit didefinisikan daripada produk fisik, karena di dalamnya mengandung banyak elemen subyektif.Penyebab rendah dan kegagalan kualitas berbeda bagi jasa dan produksi.Produksi seringkali gagal karena kesalahan disain atau tidak diproduksi sesuai spesifikasi; sedangkan kualitas layanan yang rendah biasanya berhubungan langsung dengan perilaku atau sikap pekerja, yang kurang peduli dan kurang sopan.Layanan (jasa) berbeda dengan produksi dalam beberapa hal penting berikut ini.

a) Layanan biasanya melibatkan kontak langsung antara produsen dan pengguna, sehingga kualitas layanan tergantung kepada kualitas interaksi yang ditentukan bersama antara produsen dan konsumen; sementara kualitas produksi ditentukan pemasok.

b) Waktu merupakan elemen penting dari kualitas layanan. Layanan harus diberikan tepat waktu, karena dinikmati langsung saat disajikan; dan dari interaksi langsung dapat diketahui kepuasan pelanggan.

c) Tidak seperti suatu produk, layanan tidak dapat diperbaiki seketika. Untuk alasan ini penting untuk menetapkan standar layanan, yaitu benar saat pertama dan untuk seterusnya.

d) Layanan menghadapi masalah ketidak-jelasan (intangibility), apa yang akan ditawarkan kepada 


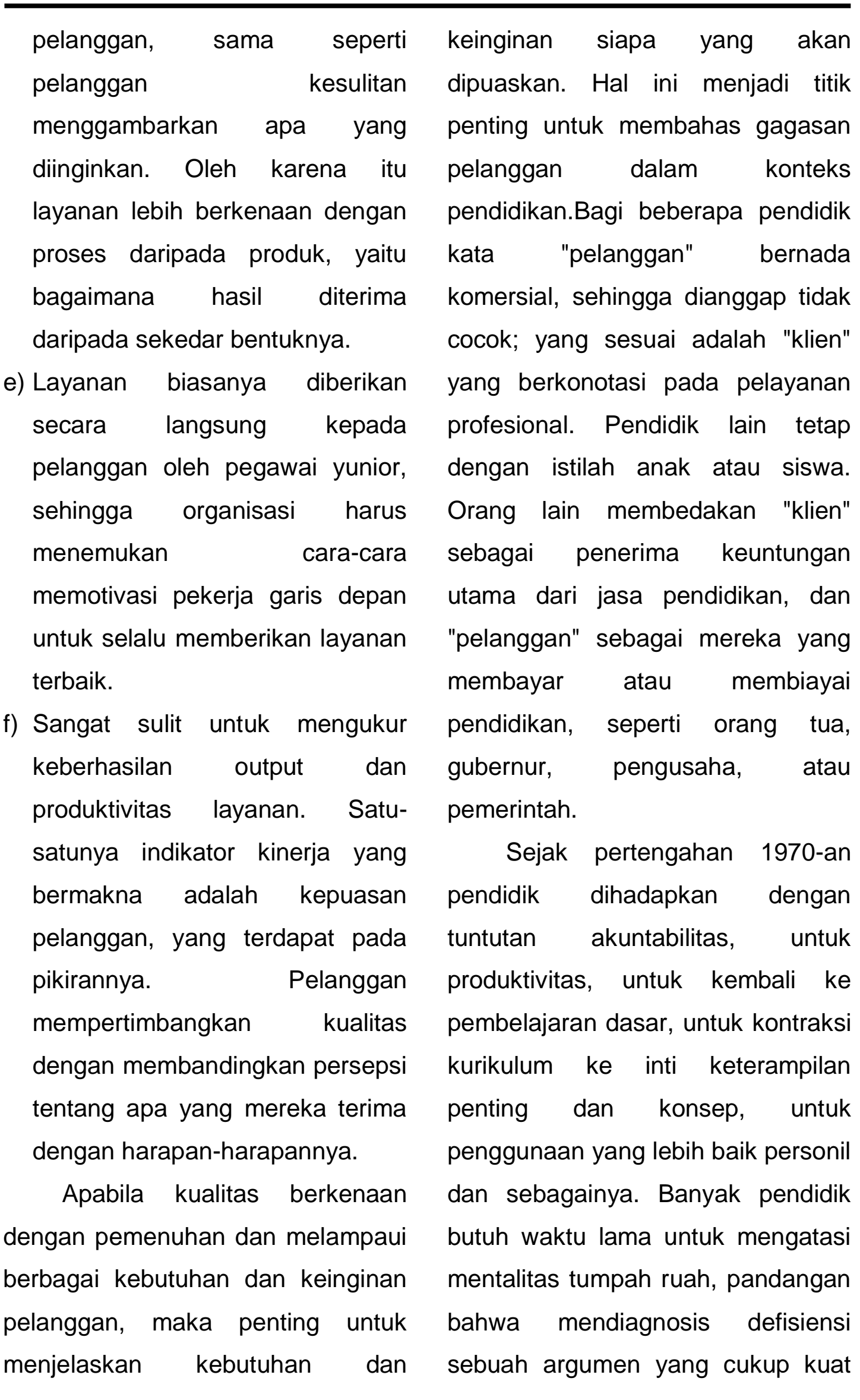


untuk lebih banyak sumber daya, mereka sama sekali tidak memahami iklim di mana administrator telah diberitahu, 'Jika anda ingin sesuatu yang lebih,maka Anda harus memberikan sesuatu sebagai trade-off. "Lebih baik menggunakan sumber daya yang ada, tidak lebih banyak sumber daya, menjadi retorika yang berlaku.

Dalam konteks ini pendidik mulai berbicara tentang sekolah efektif.Iklim publik yang mendorong konsentrasi semacam itu tersirat beberapa aksioma.Menjadi efektif sebagai sekolah bukan berarti mencari lebih banyak sumber daya, melainkan mengasumsikan pencapaian hasil yang lebih baik dengan sumber daya yang sudah Anda miliki. Menjadi efektif mengasumsikan re-konsentrasi pada apa yang merupakan dasar untuk sekolah, itu berarti menyingkirkan embel-embel dan homing pada apa yang menjadi tugas penting sekolah - mengajar siswa dan meningkatkan pelaksanaan skolastik. Menjadi efektif sering berarti harfiah meningkatkan kinerja siswa dalam membaca dan matematika.
Sekolah yang baik sering disebut sekolah yang efektif atau sekolah yang excellent atau sekolah yang unggul (Newman, 1988). Berkenaan dengan karakteristik sekolah unggul dikemukakan oleh (Sergiovanni, 1987: 33) diantaranya adalah : (1) lingkungan sekolah yang aman dan tertib; (2) iklim serta harapan yang tinggi; kepeminpinan instruksional yang logis; (4) misi yang jelas dan terfokuskan; (5) kesempatan untuk belajar dan mengerjakan tugas bagi siswa; dan (6) pemantauan yang sering dilakukan terhadap kemajuan siswa, dan hubungan rumahsekolah yang bersifat mendukung.

Sedangkan Austin (dalam Moedjiarto, 2002: 44) dalam penelitiannya menemukan bahwa sekolah-sekolah yang sukses menunjukkan saling ketergantungan sehubungan praktek-praktek tertentu dalam organisasi sekolah. Dalam kaitan ini, karakteristikkarakteristik yang ditemukan dalam sekolah-sekolah unggul, adalah (1) kepemimpinan instruksional yang kuat; (2) pengembangan program, perencanaan pengajaran; harapan-harapan performansi yang 
tinggi; (4) kepercayaan bahwa semua siswa dapat mempelajari keterampilan-keterampilan dasar; (5) iklim yang positif; pengawasan terhadap fungsi-fungsi sekolah, kurikulum dan program pengembangan staf; (7) dukungan staf yang kuat; (8) pemberian semangat; serta (9) tanggung jawab dan partisipasi siswa.

Karakteristik sekolah unggul sebagaimana dijelaskan Sergiovani dan Austin diatas, berkesesuaian dengan yang dikemukakan oleh Suyanto (2002: 53) bahwa Sekolah unggul memiliki ciri-ciri tertentu, yaitu: (1) memiliki budaya akademik yang kuat, (2) memiliki kurikulum yang selalu relevan dengan perkembangan ilmu pengetahuan dan teknologi, (3) memiliki komunitas sekolah yang selalu menciptakan cara-cara atau teknik belajar untuk belajar yang inovatif, berorientasi pada pengembangan hard knowlegde dan soft knowlegde secara seimbang, (5) proses belajar untuk mengembangkan potensi siswa secara holistik, dan (6) mengembangkan proses pengembangan kemampuan dan kompetensi ber-komunikasi siswa secara global.

Banyak persepsi yang berkembang di masyarakat kita tentang konsep sekolah unggulan. Paradigma pada umumnya adalah bahwa sekolah unggulan biasanya memerlukan uang masuk yang cukup besar, setiap tahun selalu banyak peminatnya, tingkat kelulusan yang sesuai standar nasional atau bahkan lebih, banyaknya kegiatan-kegiatan sekolah yang diselenggarakan mulai dari ekstrakurikuler, cara belajar dan lain sebagainya. Di negara-negara maju, untuk menunjukkan sekolah yang baik tidak menggunakan kata unggul (excellent) melainkan effective, develop, accelerate, dan essential. (Mohrman, 1994 : 81).

Strategi menuju sekolah unggul selama ini setidaknya ditempuh dengan model inputoutput, process-output, atau bahkan kombinasi keduanya. Perspektif input-output memandang luaran pendidikan pendidikan yang unggul karena inputnya unggul,. Kelemahan model ini antara lain cenderung eksklusif dan mengabaikan siswa atau input yang tidak unggul. 
Sementara itu perspektif processoutput memandang luaran pendidikan yang unggul akan ditentukan oleh proses yang ada termasuk didalamnya struktur persekolahan, lingkungan, corporateculture, pembelajaran efektif, dan lain-lain. Keuntungan model ini antara lain masih memperhatikan siswa unggul dan kurang unggul. Sementara itu model kombinasi dilakukan dengan memperhatikan

"minimal requirement" anak didik yang akan diterima, kualifikasi dan kompetensi guru, sarana dan prasarana yang baik serta manajemen sekolah yang efektif (Mohrman, 1994).

Strategi kebijakan yang dilakukan untuk menuju sekolah unggul berdasarkan peraturan pemerintah (PP) nomor 19 yahun 2005 tentang standar nasional pendidikan antara lain (1) proses pembelajaran diselenggarakan sedemikian rupa sehingga terasa hidup, memotivasi, interaktif, inspiratif, menyenangkan, menantang dan memberikan ruang yang cukup untuk berprakarsa, kreativitas, dan kemandirian peserta didik sesuai dengan bakat, minat dan perkembangan fisik peserta didik; (2) dalam proses pembelajaran pendidikan memberikan keteladanan; (3) untuk terlaksananya proses pembelajaran yang efektif dan efisien setiap satuan pendidikan melakukan perencanaan, pelaksanaan, penilaian proses pembelajaran dan pengawasan yang baik (Fasli Jalal, 2005).

Dengan strategi kebijakan diatas diharapkan sekolah unggul mampu menjelma menjadi

sekolah yang mampu memberikan layanan optimal kepada seluruh anak dengan berbagai perbedaan bakat, minat dan kebutuhan belajarnya; (2) sekolah mampu meningkatkan secara signifikan kapabilitas yang dimiliki anak didik menjadi aktualisasi diri yang memberikan kebanggaan; sekolah yang mampu membangun karakter kepribadian yang kuat, kokoh dan mantap dalam diri siswa; (4) sekolah yang mampu memberdayakan sumber daya yang ada secara optimal dan efektif; (5) sekolah yang mampu mengembangkan networking yang luas kepada stakeholder; 
sekolah yang mampu mewujudkan sekolah sebagai organisasi pembelajar; (7) sekolah yang responsif terhadap perubahan (Jalal, 2005). Strategi diatas berkesesuaian dengan pernyataan yang disampaikan oleh Mohrman (1994) tentang 8 (delapan) prinsip esensial dari sekolah yang memiliki performance tinggi yaitu (1) an intelectual focus directed at helping students to use their minds well; (2) simple goals related to students mastering a limited number of skills and knowledge; (3) universal goals for all students in the school; (4) personalization throught decreasing the number of student teacher teaches; (5) viewing the students as worker rather than passive receor of information; (6) student exhibitions that indicate a grasp of knowledge and skill acquisition; (7) an attitude that stresses trust and decency; (8) a staff who are generalist first and specialist second.

Efektivitas merupakan istilah yang sulit dipahami, dan harus diklarifikasi sebelum kita bisa memahami makna apa yang dimaksud dengan 'sekolah yang efektif'. Definisi dari Chester
Bamard's telah menjadi salah satu yang kuat sejak ia terlibat pada tahun 1930-an dalam bukunya Function Of The Executive.'Tindakan adalah efektif', dia berkata, 'jika menyelesaikan tujuan yang spesifik (Barnard, 1938: 20). ‘To Effect berarti membawa sekitar, untuk mencapai '; sehingga menjadi efektif, suatu tindakan atau lembaga atau individu harus membawa sesuatu, harus menyelesaikan sesuatu.Memang, istilah tersebut menyiratkan bahwa tindakan itu disengaja. Anda efektif jika Anda tentukan sendiri target dan kemudian memukulnya. Mendefinisikan target merupakan persyaratan sebelumnya sebelum sesuatu disebut efektif.

Ada perbedaan yang jelas antara 'efektivitas' dan 'efisiensi '. Keduanya berasal dari akar bahasa Latin yang sama, dan keduanya melibatkan prestasi, tetapi kata 'efisien' juga berarti produktivitas, mencapai sebuah akhir tanpa membuang karya atau sumber daya, itu berarti mendapatkan nilai untuk uang.

Jadi sekolah bisa efektif, tetapi juga tidak efisien, sekolah 
mencapai tujuannya tapi terlalu besar dalam pembiayaan. Sebuah sekolah dapat efisien (yaitu, hemat dalam penggunaan sumber daya) tapi tidak harus efektif (yaitu, baik dalam hasil yang dicapai). Sebuah sekolah yang efisien dan efektif, belum tentu baik - dalam arti menjadi yang terbaik di antara sekolah yang lain. Namun yang paling penting, sekolah tidak dapat efisien atau efektif kecuali jika memiliki tujuan, pencapaian target. Jadi diperlukan setidaknya beberapa ukuran hasil yang dapat digunakan untuk memisahkan sekolah yang efektif dari yang tingkat pertengahan atau yang tidak efektif.

\section{Bagaimana}

untuk menunjukkan sebuah efektivitas, pencapaian hasil yang dicari? Para peneliti di Amerika menggunakan indikator kinerja sebagai tes pencapaian standar nasional. Rutter, di sisi lain, menggunakan absensi, perilaku di sekolah, catatan kenakalan dan hasil pemeriksaan publik.Jadi efektivitas di Amerika Serikat berarti meningkatkan nilai rata-rata di sekolah dalam bidang matematika dan membaca.Terus terang, efektivitas sekolah selalu berarti melek huruf dan berhitung.Menilai efektivitas sekolah berdasarkan kriteria ini pasti menyebabkan keresahan kepada para pendidik.

Seperti yang kita ketahui, salah satu cara untuk meningkatkan nilai rata-rata adalah mengecualikan sampel dari siswa yang nilainya akan jatuh di bawah rata-rata dan karena itu akan menarik rata-rata ke bawah. Hal ini dapat dilakukan dengan menasihati siswa berprestasi rendah untuk pergi ke tempat lain untuk pendidikannya ; dan hal tersebut sangat memprihatinkan bahwa beberapa sekolah telah menggunakan perangkat ini selama bertahun-tahun dan dinilai sangat baik dan sesuai. Misalkan kita menilai efektivitas sebuah rumah sakit pada proporsi pasiennya yang memiliki kesehatan yang baik, cara bagi rumah sakit untuk tetap di daftar teratas adalah adanya pasien yang sudah cukup sehat atau yang memiliki probabilitas tinggi untuk pemulihan. Untuk menjaga reputasi akan keefektivitasannya, rumah sakit akan menolak untuk mengakui setiap pasien yang sakit parah atau 
penyakit yang sulit disembuhkan oleh dokter, dan tentu saja tidak akan melibatkan diri dalam seuatu yang berisiko seperti eksperimentasi dan penelitian medis.

Sangat mudah menggunakan pengukuran efektivitas ini pada akhir tahun 1970, ketika ada begitu banyak diskusi pengujian prestasi sekolah, pada tingkat melek huruf dan berhitung, dan begitu kuat kampanye tentang kembali ke dasar.'Penguasaan belajar juga tumbuh pada periode ini. Di Amerika Serikat, legislative Negara bagian diamanati dengan kompetensi dasar yang harus dimiliki setiap siswa sebelum lulus dari pendidikan umum. Dalam konteks ini antusiasme baru untuk kurikulum inti muncul.

Tetapi jika pendidik menginginkan pengakuan sekolah yang efektif dan sangat baik, mereka harus menentukan lebih tepat apa tujuan mereka, menang persetujuan - setidaknya di antara orang tua siswa - untuk tujuan tersebut, mengajarkan kepada tujuan dan kemudian secara teratur menerapkan indikator atau tindakan yang cukup jelas menunjukkan apakah kemajuan sedang dibuat ke arah tujuan tersebut. Anda tidak bisa langsung memiliki 'efektif'sekolah kecuali telah ada tujuan yang spesifik dan kemajuan dimonitor dalam beberapa cara.

Kedua, ada sesuatu yang berbahaya dan juga berhati-hati tentang fakta bahwa efektivitas sekolah memiliki daya tarik pada saat yang bersamaan saat pertanyaan tentang efisiensi, diajukan, terutama oleh para politisi dan legislatif. Penurunan ekonomi dari sekitar tahun 1975 mematikan aliran uang untuk pendidikan, sehingga tampaknya, publik haus akan inovasi, program kompensasi, perluasan pendidikan, peningkatan kualifikasi guru, ukuran kelas kecil, desain bangunan yang lebih baik dan sebagainya .

Dari beberapa hasil penelitian, pendidik harus berusaha menyusun inventarisasi kualitas yang kita harus usahakan untuk dikembangkan disekolah dalam rangka untuk membuatnya efektif. D'Amico (1982:61) mengacu pada daftar ini sebagai 'resep'; Lezotte (1982: 63) menukas bahwa itu adalah 
'kerangka kerja', bukan resep. Di tempat lain, Ron Brandt (1982: 3) mengacu pada 'katekismus baru untuk perbaikan sekolah di wilayah perkotaan.

Kita harus skeptis tentang pendekatan 'resep' seolah-olah ada satu cara terbaik untuk melakukan sesuatu; memang pendidik yang berbicara serius tentang 'keragaman' dan 'perbedaan individu' tidak harus mengadopsi praktek-praktek yang mengarah pada ketidaksesuaian baru dan perawatan standar. Oleh karena itu beberapa penulis telah menyatakan keresahan 'efektivitas' yang tergantung begitu berat pada nilai tes (lihat Brandt, 1982: 3 dan Cohen, 1981: 59). Memang lima faktor yang diformulasikan Edmonds didasarkan pada tes standar keterampilan dasar. Brandt (ibid.) memperingatkan bahwa dasar untuk efektivitas ini dapat menyebabkan praktek praktik pendidik banyak yang berpikir bijaksana: menyeragamkan kurikulum, standard promosi tetap, sebuah perguruan tinggi memerlukan program persiapan untuk setiap siswa.
Cuban (1983: 695-696)

menambahkan peringatan yang sama. la terganggu tentang 'gagasan dari kurikulum, tunggal terbaik,bergema-pra-1900 tahun sekolah umum' menegaskan kembali sendiri dan memimpin menuju 'melacak lebih seragam untuk semua siswa. la juga khawatir tentang munculnya 'cara terbaik dari pengajaran'. Dalam pencarian efektivitas berdasarkan nilai tes,ia memperingatkan, perhatian mungkin diberikan untuk 'musik, seni, keterampilan berbicara, pertumbuhan pribadi, dan harga diri'.

\section{B. Metode Penelitian}

Penelitian ini menggunakan metode penelitian survei dengan pendekatan kuantitatif. Seperti dikemukakan Masri S. (1995:21) penelitian survei dapat digunakan untuk maksud (1) penjajagan (eksploratif), (2) deskriptif, penjelasan (eksplanatory atau confirmatory), yakni menjelaskan hubungan kausal dan pengujian hipotesis; (4) evaluasi, (5) prediksi atau meramalkan kejadian tertentu di masa yang akan datang (6) penelitian operasional, dan (7) 
pengembangan indikator-indikator sosial.

Penelitian ini dilakukan di SMP Terpadu Lampang Subang Jawa Barat, yang beralamat di Kp. Lampang Kelurahan Parung Subang Jawa Barat Waktu penelitian dilaksanakan mulai April September 2014.

Penelitian dilakukan dengan tujuan untuk mendapatkan data yang komprehensif tentang kondisi sekolah dan hal-hal yang lain, melalui suatu pengumpulan data. Pengumpulan data dilakukan dengan cara mengisi kuesioner berdasarkan informasi yang diperoleh dari responden, pengamatan lapangan, dan telaah dokumentasi. Sumber data diperoleh melalui pengisian kuesioner, wawancara dan observasi kepada : (1) Kepala Sekolah; selain mengumpulkan data untuk mengetahui profil sekolah dan untuk mendapatkan data-data tentang sekolah beserta dokumen pendukungnya sesuai instrumen, khususnya yang berkaitan indikator yang menjadi tupoksi kepala sekolah. (2) Guru; wawancara dengan guru dilakukan untuk memverifikasi data-data yang berkaitan langsung dengan tugastugas guru baik sebagai tenaga pengajar maupun sebagai subsistem dari sekolah, khususnya dalam pengembangan sekolah dan pembelajaran.(3) Komite Sekolah; wawancara dengan komite sekolah dilakukan untuk memverifikasi datadata yang berkaitan langsung dengan peran komite sekolah sebagai supporting pengembangan sekolah. (4) Siswa; wawancara dengan siswa dilakukan untuk memverifikasi data-data yang berkaitan langsung dengan peran guru, khususnya dalam pelaksanaan proses pembelajaran. (5)Dinas Pendidikan Kabupaten Subang; wawancara dengan pejabat Dinas Pendidikan Kabupaten Subang yang terkait dengan penyelenggaraan, pembinaan, dan kewenangan, diantaranya tentang: kebijakan, kurikulum, pendanaan, pendidik dan tenaga kependidikan, sarana dan prasarana serta pengawasan.

Pengembangan instrument penelitian disesuaikan dengan konsep Standar Nasional Pendidikan (SNP), untuk membangun konstruk variabel yang 
akan diukur yang pada umumnya dijabarkan dalam komponen, aspek, dan indikator dari setiap SNP, demikian juga untuk pengembangan instrumen kinerja sekolah. Sehingga, dalam konteks kinerja sekolah yang tolok ukur pencapaiannya adalah standar nasional pendidikan (SNP).

Instrumen ini disusun berdasarkan delapan komponen yang mengacu pada Standar Nasional Pendidikan, baik yang tertuang dalam UUSPN No 20/2003, PP No 19/2005 dan PP No 32/2013 maupun semua Permendiknas yang mengatur tentang delapan (8) SNP yaitu untuk mengukur ketercapaian pemenuhan indikator-indikator SNP. Delapan SNP tersebut adalah standar isi, standar proses, standar kompetensi lulusan, standar pendidik dan tenaga kependidikan, standar sarana dan prasarana, standar pengelolaan, standar pembiayaan, dan standar penilaian. (selengkapnya lihat Buku Indikator SNP).

Di samping itu, juga dikembangkan atas dasar pemahaman konsep manajemen pendidikan dan mempertimbangkan kondisi lapangan dalam praktik persekolahan.Instrumen SNP memuat beberapa komponen yang memuat beberapa aspek pendidikan, dan setiap aspek memuat indikator-indikator standar nasional pendidikan, yang selanjutnya dikembangkan menjadi butir-butir pertanyaan/pernyataan.

C. Hasil Penelitian dan Pembahasan

Dengan

semakin

meningkatnya kesadaran masyarakat akan pendidikan yang berkualitas dan upaya dalam memperbaiki taraf hidup, masyarakat selalu berupaya untuk meningkatkan pendidikan. Hal inilah yang tentunya harus dapat ditangkap dan direspon oleh pemerintah daerah khususnya dan pemerintah pusat terhadap pengembangan sarana pendidikan khususnya pada tingkat dasar dan menengah.

SMP Terpadu Lampang sebagai salah satu SMP swasta yang telah menerima akreditasi dengan klasifikasi "A" (sangat bagus) memiliki peluang yang sangat besar sebagai sekolah yang 
memiliki kualitas sesuai dengan standar nasional pendidikan (SNP) sehingga dapat dikategorikan sebagai sekolah standar nasional (SSN). Hal ini ditunjukkan oleh beberapa hal yang dapat ditemukan selama proses penelitian diantaranya adalah bahwa luas lahan yang dimiliki sangat memadai yaitu sebesar $5.065 \mathrm{~m}^{2}$, sementara tingkat pencapaian UAN untuk 3 (tiga) tahun terakhir mencapai nilai yang sangat memuaskan dengan rata-rata 2011/2012 mencapai 7.50; 2012/2013 mencapai 7.77; 2013/2015 mencapai 7.50 dan 2014/2015 mencapai 7.77. dengan demikian terdapat peningkatan prestasi yang dicapai oleh siswa selama mengikuti pendidikan di SMP ini.

Tabel 1 Data Siswa SMP Terpadu

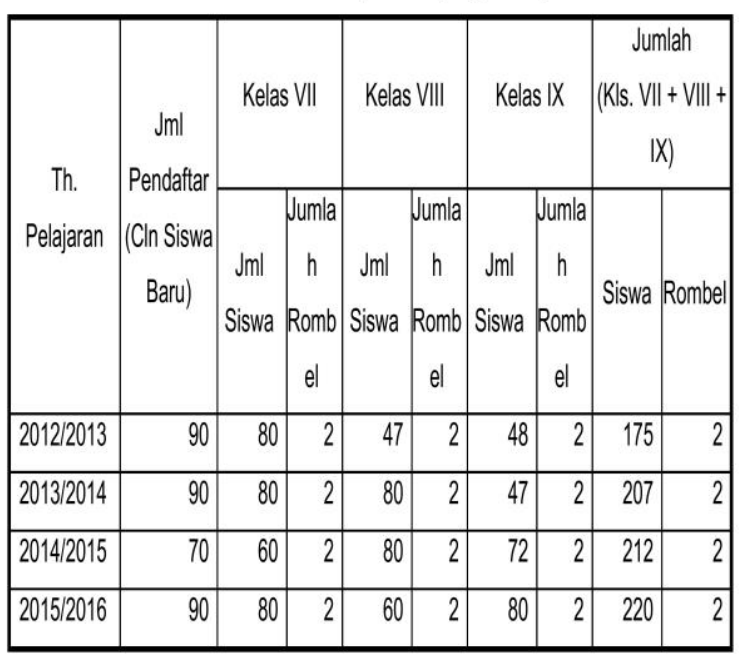

Sementara

pelaksanaan

pembelajaran pada berbagai mata pelajaran yang dilaksanakan pada Kelas VII; VIII dan IX terutama pada mata pelajaran IPA, IPS dan mata pelajaran muatan local, telah mengimplementasikan pembelajaran berbasis IT dan contextual learning. SMP ini berada sekitar 5 km dari lbu Kota Kabupaten Subang yaitu di Kelurahan Parung, sementara akses dapat dilayani baik oleh kendaraan pribadi maupun angkutan umum yang tiap hari melayani trayek Subang Jalancagak - Subang, maupun roda dua. Sementara kondisi fisik sekolah serta sarana belajar yang telah dimiliki sangat memadai dengan jumlah rombongan belajar (rombel) sebanyak 6 kelas, dengan jumlah siswa 40 orang tiap rombel. Besarnya jumlah tersebut menyesuaikan dengan daya tampung dan animo siswa sebagai bagian dari upaya untuk memberikan kesempatan kepada semua lapisan masyarakat dalam memperoleh akses pendidikan sehingga program wajib belajar dapat tuntas. 
Tabel 2.Prestasi Akademik: NUAN

\begin{tabular}{|c|l|c|c|c|c|c|c|}
\hline \multirow{2}{*}{$\begin{array}{l}\text { No } \\
\text {. }\end{array}$} & Tahun \\
\cline { 3 - 8 } & Pelajaran & & \multicolumn{5}{|c|}{ Rata-rata NUAN } \\
\cline { 2 - 8 } & $\begin{array}{c}\text { Indonesi } \\
\text { a }\end{array}$ & $\begin{array}{c}\text { Matemati } \\
\text { ka }\end{array}$ & $\begin{array}{c}\text { Bahasa } \\
\text { Inggris }\end{array}$ & IPA & Jumlah & $\begin{array}{c}\text { Rata-rata } \\
\text { tiga } \\
\text { mapel }\end{array}$ \\
\hline 1. 20132014 & 50,57 & 50,15 & 50,33 & 50,15 & 201,20 & 50,30 \\
\hline 2. 201412015 & 66,53 & 36,03 & 38,44 & 39,69 & 179,69 & 44,92 \\
\hline
\end{tabular}

Tabel 3.Prestasi Akademik:

Peringkat rerata NUAN

\begin{tabular}{|c|c|c|c|c|c|c|c|c|c|c|}
\hline \multirow[b]{3}{*}{ No } & \multirow[b]{3}{*}{ Tahun Pelajaran } & \multicolumn{9}{|c|}{ Peringkat } \\
\hline & & \multicolumn{3}{|c|}{$\begin{array}{c}\text { Tingkat Kecamatan } \\
\text { (Rayon) }\end{array}$} & \multicolumn{3}{|c|}{ Tingkat Kab/Kota } & \multicolumn{3}{|c|}{ Tingkat Propinsi } \\
\hline & & $\begin{array}{l}\text { Sek. } \\
\text { Negeri }\end{array}$ & $\begin{array}{c}\text { Sek. } \\
\text { Swast } \\
\text { a }\end{array}$ & $\begin{array}{c}\text { Sek. } \\
\text { Neger } \\
\text { dan } \\
\text { Swast } \\
\text { a }\end{array}$ & Sek. & \begin{tabular}{|} 
Sek. \\
Swast \\
a
\end{tabular} & \begin{tabular}{|c|} 
Sek. \\
Negeri \\
dan \\
Swast \\
a
\end{tabular} & $\begin{array}{l}\text { Sek. } \\
\text { Negeri }\end{array}$ & $\begin{array}{c}\text { Sek. } \\
\text { Swast } \\
\text { a }\end{array}$ & \begin{tabular}{|c} 
Sek. \\
Neger \\
dan \\
Swast \\
a
\end{tabular} \\
\hline 1. & 2013/2014 & 26.95 & 26.30 & 26.62 & 25.81 & 25.85 & 25.83 & & & \\
\hline 2. & 2014/2015 & 54.16 & 48.00 & 51.00 & 48.16 & 50.00 & 49.08 & & & \\
\hline
\end{tabular}

Meskipun SMP Terpadu Lampang belum mencapai prestasi pada beberapa tahun terakhir, namun semangat untuk maju dan berprestasi sangat tinggi, hal ini terbukti dengan semakin beragamnya upaya yang dilakukan pihak sekolah dalam memacu potensi meskipun belum mendapatkan hasil maksimal.Namun hal tersebut tidak mengendorkan semangat dan keyakinan semua komponen SMP Terpadu Lampang untuk dapat menjadi sekolah SSN dengan baik.
Tabel 4.Angka Kelulusan dan

Melanjutkan

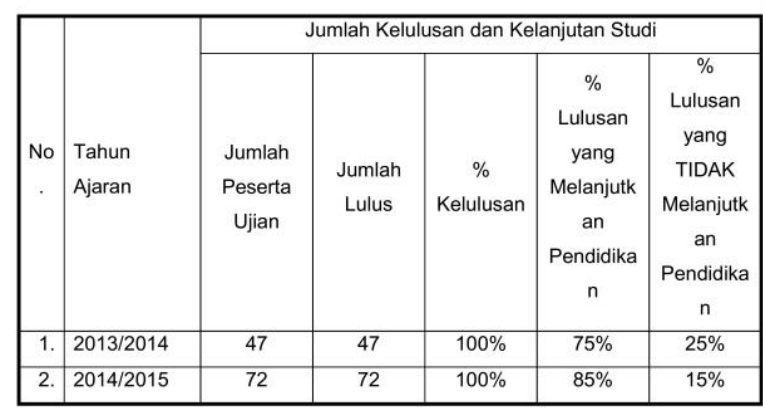

Bahkan pada beberapa program pengembangan selanjutnya diarahkan pada pencapaian UAN dan prestasi non akademis lainnya.Sementara upaya yang sedang digiatkan pada bidang akademis adalah dengan pembentukan kelompok belajar yang diharapkan dapat timbul semangat untuk belajar dan mencapai prestasi dalam berbagai bidang olimpiade yang diselenggarakan baik pada tingkat kabupaten, proinsi bahkan nasional.

Secara khusus pengembangan RKAS berkaitan dengan 8 standar nasional pendidikan (SNP) pada sekolah ini telah dilaksanakan dengan baik, bahkan hasilnyapun telah cukup dirasakan oleh seluruh masyarakat dalam beberapa tahun, sehingga harapan masyarakat sekolah ini dapat lebih berkembang menjadi sekolah unggul. 
Menurut rencana
pengembangan sekolah dalam
RKAS yang telah dibahas dan
disetujui bersama oleh segenap
komponen sekolah bersama komite
dan diketahui oleh Dinas Pendidikan

Kabupaten Subang diketahui bahwa program dapat dilalksanakan dengan baik bahkan mendapat dukungan penuh dari masyarakat. Beberapa program yang telah dan sedang berjalan adalah :

a. Pemenuhan kebutuhan sarana pembelajaran berbasis ICT

b. Pemenuhan kebutuhan media pembelajaran untuk masingmasing kelas dan ruang guru berbasis ICT, melalui bengkel kerja guru

c. Pemenuhan bahan ajar berbasis ICT dan buku

d. Peningkatan pembelajaran proses kreativitas

e. Pemenuhan informasi akademis berbasis ICT

f. Pembinaan potensi nonakademik berupa olah raga, dan seni

g. Pengembangan potensi siswa berbakat
Beberapa kegiatan tersebut telah dan sedang dilaksanakan oleh seluruh komponen sekolah dengan dukungan penuh dari masyarakat dengan harapan bahwa mutu lulusan dapat lebih ditingkatkan sehingga dapat menjadi kebanggaan bagi seluruh masyarakat Kabupaten Subang.

Berdasarkan pengamatan dan kondisi riil dilapangan serta mengamati beberapa kegiatan yang telah dilaksanakan bertolak dari instrument yang telah dikembangkan, maka dapat dijelaskan beberapa hal yang berkaitan dengan keberlanjutan program peningkatan kualitas pembelajaran pada SMP Terpadu Lampang di Kabupaten Subang adalah sebagai berikut :

a. Keberlanjutan program peningkatan dan pengembangan kualitas pembelajaran sebagai suatu bagian penting dari tujuan untuk meningkatkan kualitas sekolah pada umumnya, dan sekolah standar nasional (SSN) pada khususnya. Beberapa cerminan pelaksanaan SSN yang berlanjut pada sekolah ini adalah telah dilaksanakannya 
pembelajaran contextual learning sebagai kelanjutan program peningkatan mutu pembelajaran yang pada akhirnya berdampak pada peningkatan kualitas lulusan.

b. Pelaksanaan SSN yang telah berjalan mengisyaratkan bahwa pelaksanaan program SSN harus mendapat dukungan penuh dari seluruh stakeholder disekolah khususnya pemerintah daerah, hingga saat ini pelaksanaan program telah mendapat dukungan justru dari masyarakat melalui komite sekolah yang secara aktif berperan dalam mengembangkan sekolah menjadi lebih baik.

c. Hingga saat ini pengembangan pendanaan program telah mencapai tingkat yang sangat besar dalam RKAS khususnya di SMP Terpadu Lampang dengan rincian meliputi pengembangan program pengembangan sarana fisik dan non-fisik serta pengembangan proses belajar mengajar yang diperoleh dari dana BOS, sumbangan sukarela masyarakat dan sumbangan pengembangan kelas bilingual.
Beberapa hasil temuan dalam penelitian di SMP Terpadu Lampang Kabupaten Subang dapat disampaikan sebagai berikut :

1. Standar Kompetensi Lulusan telah mencapai nilai yang memuaskan dengan tingkat pencapaian lulusan 3 (tiga) tahun terakhir mencapai $100 \%$ dengan rata-rata pencapaian untuk 4 (empat) mata pelajaran mencapai 8,48. dengan nilai mata pelajaran tertinggi pada mata pelajaran IPA, Matematika dan Bahasa Inggris.

2. Standar Isi meliputi Prosentase "kelengkapan" perangkat KBK (konsep dasar, silabus, prota,prosem/pemetaan, penilaian, RPP, dll) untuk kelas 7, 8, dan 9 (dokumentasi), prosentase guru yang telah memiliki dokumentasi KBK secara lengkap, prosentasi implementasi KBK di sekolah telah tercapai dengan baik dimana semua guru dan pimpinan sekolah telah cukup memahami semua perangkat dan memiliki kelengkapan tersebut. 
3. Proses Belajar Mengajar dalam aspek ini sekolah telah melaksanakan program pembelajaran sesuai dengan kemampuan dan target yang telah ditetapkan dalam standar pendidikan nasional meskipun dengan keterbatasan sarana dan prasarana yang dimiliki khususnya dalam hal Prosentase guru yang telah mengimplementasikan CTL dalam proses pembelajaran, prosentase guru dalam menggunakan media pembelajaran, prosentase kepemilikan (jumlah) media pembelajaran untuk semua mata pelajaran, prosentase rata-rata kehadiran guru dalam mengajar telah mencapai hampir lebih dari $90 \%$.

4. Tenaga Pendidik dan kependidikan sebagai aspek dasar dalam pelaksanaan pembelajaran memiliki posisi yang paling strategis, oleh karenanya pengembangan kemampuan tenaga pendidik dan kependidikan memiliki perhatian serius khususnya rasio jumlah guru terhadap rombongan belajar, prosentase guru berkualifikasi S1 (terhadap jumlah guru keseluruhan), prosentase guru kesesuaiannya bidang keahlian terhadap tugas mengajarnya telah tercapai dengan baik, bahkan dalam pengembangan kemampuan guru mencapai pendidikan tertinggi serta pelatihan baik CTL maupun KTSP telah dilaksanakan dengan baik. Bahkan dalam pengembangan selanjutnya telah direncanakan pengembangan pendidikan guru untuk mencapai strata S2.

5. Sarana dan Prasarana, sebagai sekolah yang berada jauh dipusat kota dan berada di sisi paling timur pulau memiliki hambatan transportasi, sehingga informasi dan pengembangan sarana dan prasarana menjadi kendala yang cukup serius khususnya dalam pemenuhan kebutuhan sarana labratorium baik IPA maupun ICT khususnya Rasio ruang kelas terhadap rombongan belajar, jumlah laboratorium IPA yang dimiliki, jumlah laboratorium Komputer yang dimiliki, jumlah 
laboratorium Bahasa yang dimiliki, internet untuk siswa yang dimiliki, rasio buku terhadap siswa, jumlah komputer untuk siswa yang dimiliki telah terpenuhi dengan menggunakan pengembangan berbasis ICT, sehingga setiap kelas dan ruangan telah terkoneksi dengan internet sehingga sangat mendukung dalam pengembangan sumber belajar siswa.

6. Manajemen/Pengelolaan sebagai suatu system pengelolaan di sekolah memiliki peran penting dalam menunjang pelaksanaan program untuk mencapai visi dan misi sekolah sesuai dengan tujuan pendidikan nasional. Dalam pengelolaan ini kepala sekolah memiliki peran yang cukup penting dengan dukungan dari semua staff dan komponen sekolah termasuk siswa. Beberapa dokumentasi administrasi sekolah, prosentase keterlibatan (partisipasi) stakeholder dalam pengambilan keputusan berjalan secara sinergis antara sekolah dengan stakeholder khususnya kerjasama dengan komite sekolah sangat signifikan dalam pengembangan sekolah.

7. Pembiayaan Pendidikan merupakan aspek penting dalam penyelenggaraan pendidikan dan proses belajar mengajar, namun sejak bergulirnya BOS dan pendidikan gratis telah mematikan kreatifitas masyarakat dalam turut mengembangkan dan mendukung sekolah dalam proses pengembangan, terlebih dukungan pemerintah daerah baik propinsi maupun kabupaten, khususnya dalam pengamatan total anggaran belanja sekolah (RAPBS) per tahunnya, namun dalam pelaksanaan proses pembiayaan selanjutnya sekolah ini telah mampu menggali dana dari masyarakat cukup besar bahkan jumlah sumber dana sekolah pada SMP ini menjadi lebih variatif.

8. Penilaian sebagai suatu hal yang sangat dibutuhkan dalam melihat pencapaian proses belajar selama waktu berjalan memiliki peranan yang sangat penting oleh karenanya pengamatan 
terhadap prosentase guru yang telah mengimplementasikan penilaian yang sesungguhnya (autenthic assessment) atau berbasis kelas, prosentase kelengkapan dokumen penilaian pada sekolah ini telah dilaksnakan dengan baik khususnya dalam pencapaian KKM yang telah mencapai lebih dari 75. bahkan pencapaian siswa mencapai lebih dari $85 \%$.

Sebagai sekolah yang telah dikembangkan selama beberapa tahun, SMP Terpadu Lampang telah layak sebagai SSN dengan beberapa pertimbangan diantaranya adalah kesiapan sekolah secara umum dalam pengembangan. Potensi lain yang dapat dikembangkan oleh sekolah bersama dengan komponen sekolah diantaranya adalah pencapaian akreditasi mencapai A, bahkan penilaian akreditasi mencapai katogori Amat Baik.

Beberapa dokumen yang digunakan untuk mengungkap keberadaan dokumen sekolah sebagai pembuktian terhadap perencanaan, pelaksanaan, dan hasil-hasil kegiatan, termasuk keuangan.berdasarkan criteria pelaksanaan proses pembelajaran dan pengelolaan pendidikan menunjukkan bahwa pencapaian penilaian dokumen portofolio untuk sekolah ini telah mencapai nilai yang sangat memuaskan. Beberapa dokumen yang sangat menonjol diantaranya adalah dokumen Dokumen SKL, Piagam/setifikat Prestasi akademik , Piagam /Sertifikat Prestasi non-akademik, KKM per Mata Pelajaran, KTSP, Kalender Akademik, Pembagian Tugas mengajar guru, RPP, Materi Bahan Ajar, Media pembelajaran, dokumen guru, staff dan kepala sekolah, Sertifikat tanah/surat keterangan tanah, Master plan rencana pengembangan, Maket Pengembangan Sekolah, Foto/file gambar fasilitas atau sarpras sekolah dan lingkungan sekolah, Sertifikasi Akreditasi Sekolah, Dokumen Rencana Pengembangan Sekolah, Dokumen Regulasi/ peraturan sekolah, Laporan Pengembangan Sekolah, Cetakan profil sekolah tahun terakhir, Dokumen kerjasama pembiayaan sekolah, Dokumen Laporan Keuangan, Bukti Setor pajak tahun 
terakhir,

Instrumen/soal-soal

penilaian/tes, Contoh hasil validasi

instrumen, Hasil penilaian/tes.

\section{Kesimpulan}

Berdasarkan hasil penelitian, setelah melihat, mengamati, menilai dan melakukan wawancara terhadap semua komponen sekolah dan informasi yang diberikan oleh dinas pendidikan Kabupaten Subang selama pelaksanaan dapat disimpulkan sebagai berikut

Pelaksanaan program sekolah dalam pencapaian SNP telah terlaksana dengan baik dan berjalan dengan lancar. Pelaksanaan program yang telah dilaksanakan pada semua kelas telah memberikan dampak yang cukup signfikan terhadap peningkatan kualitas akademik maupun nonakademik. Tingkat ketercapaian program yang telah disusun dalam RPS telah mencapai $90 \%$ dengan target utama adalah pencaian tingkat UAN dan kelulusan yang telah dilaksanakan oleh guru baik dalam penyusunan RPP dan bahan ajar telah mencapai 85\%, sementara pelaksanaan program lain masih berjalan dengan baik. Potensi akademik yang dapat dikembangkan diantaranya adalah keikutsertaan dalam setiap perlombaan dan olimpiade tingkat Kabupaten dan Propinsi bahkan Nasional, dengan pembinaan dan dukungan baik dari guru-guru, Dinas Pendidikan Kota maupun orang tua dan Komite Sekolah

Manajemen yang dikembangkan SMP Terpadu Lampang menyumbangkan nilai yang cukup siginifikan terutama dalam perencanaan dan implementasi program, sementara pengawasan dan kepemimpinan Kepala Sekolah telah berjalan dengan baik, sehingga nilai yang didapat cukup signifikan, sementara komponen lainnya yang cukup menonjol adalah PBM dan standar isi yang mendapatkan nilai yang cukup baik, sehingga dapat dikembangkan lebih lanjut.

Berdasarkan hasil analisis data dan kondisi sekolah secara keseluruhan melalui pengamatan dan evaluasi integral, maka dapat dikatakan bahwa SMP Terpadu Lampang telah melaksanakan program sekolah dengan baik, dengan dukungan dari semua stake 
holder baik orang tua dan masyarakat, pemerintah daerah baik kabupaten maupun propinsi serta pemerintah pusat. Oleh karenanya dapat dikatakan bahwa sekolah ini layak sebagai SSN dengan beberapa pengembangan lanjut khususnya sarana dan prasarana laboratorium bahasa, IPA, TIK dan Matematika, meskipun dukungan masyarakat dalam pembiayaan cukup minim, yang dikarenakan oleh rendahnya pemahaman sebagian masyarakat dalam mensikapi program sekolah gratis.

\section{DAFTAR PUSTAKA}

Alan, Thomas, J, (1971). The Productive School; A System Analysis Approach to Educational Administration. New York : John Willey \& Sons, Inc.

Bloom, Benjamin S. (1976).Human Characteristics and School Learning. New York: McGraw-Hill Book Company.

Cohn, Elchanan (1979), The Economics of Education Massachusetts Cambridge : Ballinger Publishing Company
Colin Marsh, (2008), Becoming a Teacher : Knowledge, Skills, and Issues, 4th Edition, Pearson Education Australia.

Deming, W.E. (1989), Foundation for Management of Quality in the Western World, New York, NY : Perigee Books,.

Domingo, R.T. (1997). Quality Means Survival: Caveat Vendidor, Let the Seller Beware. Singapore: Simon and Schuster (Asia) Pte.Ltd.

Jalal, Fasli dan Supriadi Dedi, (2001).Reformasi Pendidikan dalam Konteks Otonomi Daerah, Yogyakarta : Adicitra Karya Nusa

Jalal, F. (2005).Kebijakan Pendidikan dalam

Profesionalisasi Pendidik dan Tenaga kependidikan dalam Upaya Meningkatkan Kualitas Pendidikan. Bandung: FIP UPI.

Lawrence C. Scharmann.(2007). A Dynamic Professional Development School Partnership in Science Education.The Journal of Educational Research. Copyright (C) 2007 Heldref 
Didaktik : Jurnal Pendidikan Guru Sekolah Dasar, ISSN : 24775673

Sekolah Tinggi Keguruan dan IImu Pendidikan Subang Volume IV Nomor 1, Juli 2018

Publications March/April 2007

[Vol. 100(No. 4)]

Suyanto, (2002).Tantangan Global

Pendidikan

Nasional.

Grasindo: Jakarta.

Suyanto, (2007), “Tantangan Profesionalisme Guru di Era Global', Pidato Dies Natalis ke-43 Universitas Negeri Yogyakarta, 21 Mei.

Suyanto, (2008), Dialog Interaktif Tentang Pendidikan (dari konseptual menggelitik sampai yang ringan dan ringan sekali), Multi

Pressindo, Yogyakarta

Terry, George, (1960), Principles of Management, Home-wood Illionis: Richard D. Irwin

Tilaar, H.A.R., (2004). Manajemen Pendidikan Nasional. Bandung: PT. Remaja Rosda Karya.

Tilaar, H.A.R., (2006). Standarisasi Pendidikan Nasional: Suatu Tinjauan Kritis. Jakarta: Rineka Cipta. 